\title{
THE DEVELOPMENT OF CIRCULAR WIRE MAGNETIC INDUCTION EXPERIMENT DEVICE AS PHYSICS LEARNING MEDIA
}

\author{
Novia Ariyani $^{* 1)}$, Hendar Sudrajat ${ }^{2)}$, Zulirfan $^{3)}$, Rudi Sisyanto ${ }^{4)}$, Hernelis $\mathbf{R}^{5)}$ \\ ${ }^{1,2,3)}$ Physics Education, University of Riau \\ 4,5) SMAN 8 Pekanbaru \\ e-mail: noviaariyani.na@gmail.com \\ zirfanaziz69@gmail.com
}

\begin{abstract}
In general, this research aims to produce a valid magnetic induction experimental device as a medium for learning physics in high school. The experimental device consists of experimental equipment and tool usage manual. In particular, this research aims to design, build, and validate devices for magnetic induction experiments on coiled wire as a physics learning media according to the research development steps. Three experts and two physics teachers as users have been involved to provide an assessment of the experimental devices that have been built. Assessment is carried out on the construction and content of the experimental device. The results of data analysis showed that every aspect of the assessment of the experimental tool was declared valid with a very good category (index validity 3.34) and the manual for using experimental tools was also declared valid with a very good category (index of validity 3.47). Thus, it can be said that the magnetic induction experimental device in circular wire is declared valid as a medium for physics learning.
\end{abstract}

Keywords : magnetic induction of circular wire, physic experimental device, physics learning media.

\section{PENGEMBANGAN PERANGKAT EKSPERIMEN INDUKSI MAGNETIK KAWAT MELINGKAR SEBAGAI MEDIA PEMBELAJARAN FISIKA SMA}

\author{
Novia Ariyani ${ }^{{ }^{* 1)}}$, Hendar Sudrajat ${ }^{2)}$, Zulirfan ${ }^{3)}$, Rudi Sisyanto ${ }^{4)}$, Hernelis $\mathbf{R}^{5)}$ \\ 1) Pendidikan Fisika, Universitas Riau \\ ${ }^{2)}$ SMAN 8 Pekanbaru \\ e-mail: noviaariyani.na@gmail.com \\ zirfanaziz69@gmail.com
}

\begin{abstract}
Abstrak
Secara umum penelitian ini bertujuan untuk menghasilkan sebuah perangkat eksperimen induksi magnetik yang valid sebagai media pembelajaran fisika di SMA. Perangkat eksperimen terdiri dari peralatan eksperimen dan buku panduan penggunaan alat. Secara khusus penelitian ini bertujuan untuk mendesain, membangun, serta memvalidasi perangkat eksperimen induksi magnetik pada kawat melingkar sebagai media pembelajaran fisika sesuai dengan langkah-langkah penelitian pengembangan. Tiga pakar dan dua orang guru fisika sebagai pengguna telah dilibatkan untuk memberikan penilaian terhadap perangkat eksperimen yang telah dibangun. Penilaian dilakukan terhadap konstruksi dan isi dari perangkat eksperimen. Hasil analisis data menunjukkan bahwa setiap aspek penilaian alat eksperimen dinyatakan valid dengan kategori sangat baik (indeks validitas 3,34 ) dan buku panduan penggunaan alat eksperimen juga dinyatakan valid dengan
\end{abstract}

${ }^{*}$ Komunikasi Penulis 
kategori sangat baik (indeks validitas 3,47). Dengan demikian, dapat dikatakan bahwa perangkat eksperimen induksi magnetik pada kawat melingkar dinyatakan valid sebagai media pembelajaran fisika.

Kata Kunci: induksi magnet kawat melingkar, perangkat eksperimen fisika, media pembelajaran fisika.

\section{Pendahuluan}

Kemajuan suatu bangsa ditentukan dari bagaimana perkembangan pendidikan bangsa tersebut. Kemajuan dalam satuan waktu jangka panjang akan dapat memprediksi kualitas bangsa pada sekian puluh tahun ke depan. Akhir dari hasil pendidikan yang terencana menghasilkan masyarakat rata-rata berpendidi kan tinggi. Masyarakat yang maju akan melahirkan kemajuan dalam berbagai bidang seperti pembangunan, ilmu pengetahuan, teknologi, ekonomi, sosial, politik, dan peradaban.

Hal ini menunjukkan keberadaan pendidikan demikian pentingnya. Untuk memperoleh pendidikan yang maju, tinggi, dan berkembang perlunya suatu perencanaan yang berhubungan dengan tujuan nasional pendidikan bangsa (Ali Hamzah, 2014). Dalam Sistem Pendidikan Nasional Nomor 20 Tahun 2003 dinyatakan bahwa tujuan pendidikan nasional Indonesia adalah untuk mencetak generasi bangsa yang beriman bertakwa, berbudi luhur, cerdas, dan kreatif.

Kemajuan suatu bangsa ditentukan oleh kemajuan sains dan teknologi di Negara tersebut. Salah satu mata pelajaran di sekolah, yang sangat mendukung kemajuan sains dan teknologi adalah pelajaran fisika.

Konsep fisika itu dapat diamati pada fenomena-fenomena yang terjadi dalam kehidupan maupun lingkungan sehari-hari. Ada fenomena yang jelas terlihat dan dirasakan oleh alat indra. Namun ada yang tidak bisa karena keterbatasan alat indra manusia. Jika tidak digunakan alat bantu dalam mempelajarinya, siswa akan kesulitan mengamati fenomena yang sedang dipelajari. Dengan demikian siswa hanya mengetahui fenomena dari penjelasan verbal guru. Padahal perjelasan verbal diterima dan diproses oleh siswa secara berbeda-beda. Bagi siswa yang sulit berimajinasi, dia hanya akan terbiasa menghafal konsep fisika tanpa tahu gambaran proses secara nyata. Siswa yang mampu berimajinasi tidak berarti menjadi lebih paham, karena penjelasan tersebut akan divisualisasikan secara berbeda-beda oleh tiap siswa sesuai tingkat imajinasinya. Dengan begitu siswa tidak dapat menguasai konsep secara tepat sehingga mengakibatkan terjadinya miskonsepsi (Ika Risqi, 2014).

Salah satu fenomena konsep fisika yang sulit diamati dalam kehidupan sehari-hari oleh alat indra adalah konsep induksi mangnetik. Konsep ini terdapat dalam materi medan magnet yang diajarkan pada KD 3.6 dan 4.6 di kelas XII SMA pada kurikulum 2013. Sesuai dengan kompetensi dasar ranah pengetahuan, siswa diharapkan mampu menganalisis induksi magnet dan gaya magnet diberbagai produk teknologi serta dalam ranah penerapan pengetahuan, siswa diharapkan mampu mengamati induksi magnet dan gaya magnet disekitar kawat berarus. Dari hasil survei yang dilakukan oleh Muhammad Ivan, et al., (2015) pada beberapa sekolah di Jakarta didapati bahwa $73,3 \%$ siswa dan guru menyatakan materi medan magnet merupakan materi yang sulit dipahami. Disamping itu sekitar 75,6\% guru mengajarkan konsep medan magnet dengan materi ceramah dan hanya sekitar $2,22 \%$ guru yang melakukan praktikum, hal ini dikarenakan keterbatasan dan kekurang efektifan alat praktikum sehingga kurang mampu memperlihatkan berbagai variabel yang mempengaruhi medan magnet oleh kawat berarus listrik.

Materi induksi magnetik dianggap sangat penting karena prinsip induksi magnet diaplikasikan dalam berbagai produk teknologi dalam kehidupan sehari-hari. Namun materi ini bersifat teori dan termasuk konsep induksi magnetik terasa begitu abstrak sehingga guru kesulitan mengajarkannya kepada siswa. Hal ini sesuai dengan hasil penelitian Sulvia Nur Oktafiani, et al., (2015) yang menjelaskan bahwa gejala induksi magnetik tidak dapat dilihat langsung diamati oleh mata siswa sehingga siswa merasa sulit membayangkan visualisasinya dalam bentuk gambar. Permasalahan yang sering ditemukan dalam pembelajaran konsep induksi magnetik adalah 
guru jarang sekali menerapkan metode eksperimen, lebih cenderung menggunakan metode ceramah untuk menyampaikan materi pelajaran yang disebabkan oleh beberapa faktor yakni keterbatasan waktu, keterbatasan perangkat eksperimen, materi yang padat, dan tidak adanya laboran di sekolah. Jadi untuk mengatasi terkendalanya pelaksanaan eksperimen dan membuat konsep induksi elektromagnetik, maka pembelajaran pada materi ini perlu menggunakan metode yang sesuai, yaitu metode eksperimen.

Selain metode yang sesuai untuk mengatasi masalah keabstrakan materi pembelajaran induksi magnetik bagi siswa, maka diperlukan media pembelajaran yang dapat menjelaskan konsep fisika ini. Media merupakan sebuah alat yang mempunyai fungsi menyampaikan pesan. Media menjadi sarana penghubung dan komunikasi yang baik antara dua belah pihak dan digunakan semua kalangan masyarakat (Irnin Agustina Dwi Astutia, et al., 2017). Dalam pembelajaran media digunakan untuk menyampaikan dan menyalurkan pesan dari sumber (guru) secara terencana sehingga tercipta lingkungan belajar yang kondusif di mana penerimanya (siswa) dapat melakukan proses belajar secara efisien dan efektif (Munadi Yudhi, 2010). Media pembelajaran selalu terdiri atas dua unsur penting, yaitu unsur peralatan atau perangkat keras (hardware) dan unsur pesan yang dibawanya (message/software). Dengan demikian media pembelajaran memerlukan peralatan untuk menyajikan pesan, namun yang terpenting bukanlah peralatan itu, tetapi pesan atau informasi belajar yang dibawakan oleh media tersebut (Cepy Riyana, 2012).

Untuk eksperimen induksi magnetik pada kawat lurus, Muhammad Ridho (2017) telah membuat perangkat eksperimen yang memudahkan guru dan siswa dalam memvisualisasikan induksi magnetik. Namun belum dikembangkan peralatan untuk induksi magnetik oleh kawat melingkar. Untuk memvisualisasikan induksi magnet oleh kawat melingkar maka peneliti mengembangkan satu unit perangkat eksperimen induksi magnetik pada kawat melingkar. Selain itu, diharapkan pembelajaran materi listrik magnet tidak lagi dianggap abstrak dan sulit oleh siswa.

Terkait pembahasan materi medan magnet, Oersted menemukan bahwa di sekitar arus listrik terdapat medan (induksi) magnet yang mempengaruhi kedudukan jarum kompas (Tipler, 2001). Besarnya medan magnet di sekitar kawat berarus listrik tersebut dipengaruhi oleh besarnya kuat arus listrik dan jarak titik tinjauan terhadap kawat (Muhammad Suin, 2012). Hal ini berarti semakin besar arus listrik yang digunakan semakin besar pula medan magnetik yang dihasilkan (Afdan, 2012). Selain besarnya medan magnet apabila penghantar berarus listrik ditempatkan dalam medan magnet akan mengalami gaya magnet yang dikenal dengan Gaya Lorentz (Giancoli, 2001).

Secara keseluruhan materi medan magnet ini memiliki keterkaitan satu sama lain yang diharapkan dapat dijelaskan lebih mudah dan tergambar dengan jelas oleh siswa melalui perangkat eksperimen induksi magnetik ini.

\section{Bahan dan Metode}

Penelitian pengembangan perangkat eksperimen induksi magnetik pada Kawat Melingkar sebagai Media Pembelajaran Fisika dilakukan di Laboratorium Pengembangan Media Pembelajaran Pendidikan Fisika Prodi Pendidikan Fisika Jurusan PMIPA Fakultas Keguruan dan Ilmu Pendidikan Universitas Riau. Waktu penelitian dimulai dari bulan Desember 2018 hingga April 2019.

Jenis dan kriteria produk penelitian yang dimaksud dalam penelitian ini adalah alat eksperimen induksi magnetik pada kawat melingkar dan panduan penggunaan alat eksperimen. Pengembangan perangkat eksperimen induksi pada kawat melingkar melewati beberapa tahap untuk menghasilkan produk yang dapat digunakan sebagai media pembelajaran fisika di SMA. Penelitian ini menggunakan metode Research and Development dengan jenis penelitian pengembangan. Prosedur penelitian yang digunakan diadaptasi dari prosedur penelitian Research and Development menurut N. J Manson dalam M. Rusdi, 2018 seperti pada Gambar 1.

Data yang dikumpulkan adalah data primer yang diperoleh dari angket lembar validasi yang telah diisi validator. Instrumen yang digunakan untuk pengujian validitas terdiri dari penilaian validasi isi. Aspek-aspek instrumen yang dinilai untuk alat dan panduan penggunaan alat eksperimen induksi magnetik 
pada kawat melingkar diperlihatkan pada Tabel 1 dan Tabel 2.

Teknik pengumpulan data pada penelitian pengembangan perangkat eksperimen induksi magnetik dilakukan dengan cara memberikan angket lembar validasi kepada validator. Validator dalam penelitian ini adalah tiga orang dosen dan dua orang guru. Validator memberikan penilaian dan saran untuk perbaikan perangkat eksperimen tersebut bedasarkan kriteria yang tertulis dalam lembar validasi yang diberikan. Teknik analisis data yang digunakan dalam penelitian ini adalah analisis deskriptif, yakni dengan cara menghitung skor validitas setiap instrumen penilaian perangkat eksperimen kemudian dilakukan penarikan kesimpulan. Menurut (Khobibah dalam Siti Maghfirotun dan Heri Kiswanto, 2011) langkah-langkah dalam perhitungan mencapai nilai validasi dijelaskan sebagai berikut: 1). Melakukan rekapitulasi data penilaian kevalidan produk ke dalam tabel yang meliputi indikator $\left(\mathrm{K}_{\mathrm{i}}\right)$, aspek $\left(\mathrm{A}_{\mathrm{i}}\right)$ dan nilai validasi $\left(\mathrm{V}_{\text {media }}\right)$ untuk masingmasing validatorm, 2). Menentukan rata-rata nilai hasil validasi dari semua validator untuk setiap indikator, 3) Pengkategorian kriteria tingkat validitas diberikan pada Tabel 3.

Perangkat eksperimen yang dikembangkan dalam penelitian ini dikemas dalam dua komponen, yaitu alat eksperimen induksi magnetik pada kawat melingkar dan panduan penggunaan alat eksperimen induksi mangetik pada kawat melingkar.

Perangkat eksperimen yang dikembangkan dalam penelitian ini dikemas dalam dua komponen, yaitu alat eksperimen induksi magnetik pada kawat melingkar dan panduan penggunaan alat eksperimen induksi mangetik pada kawat melingkar.

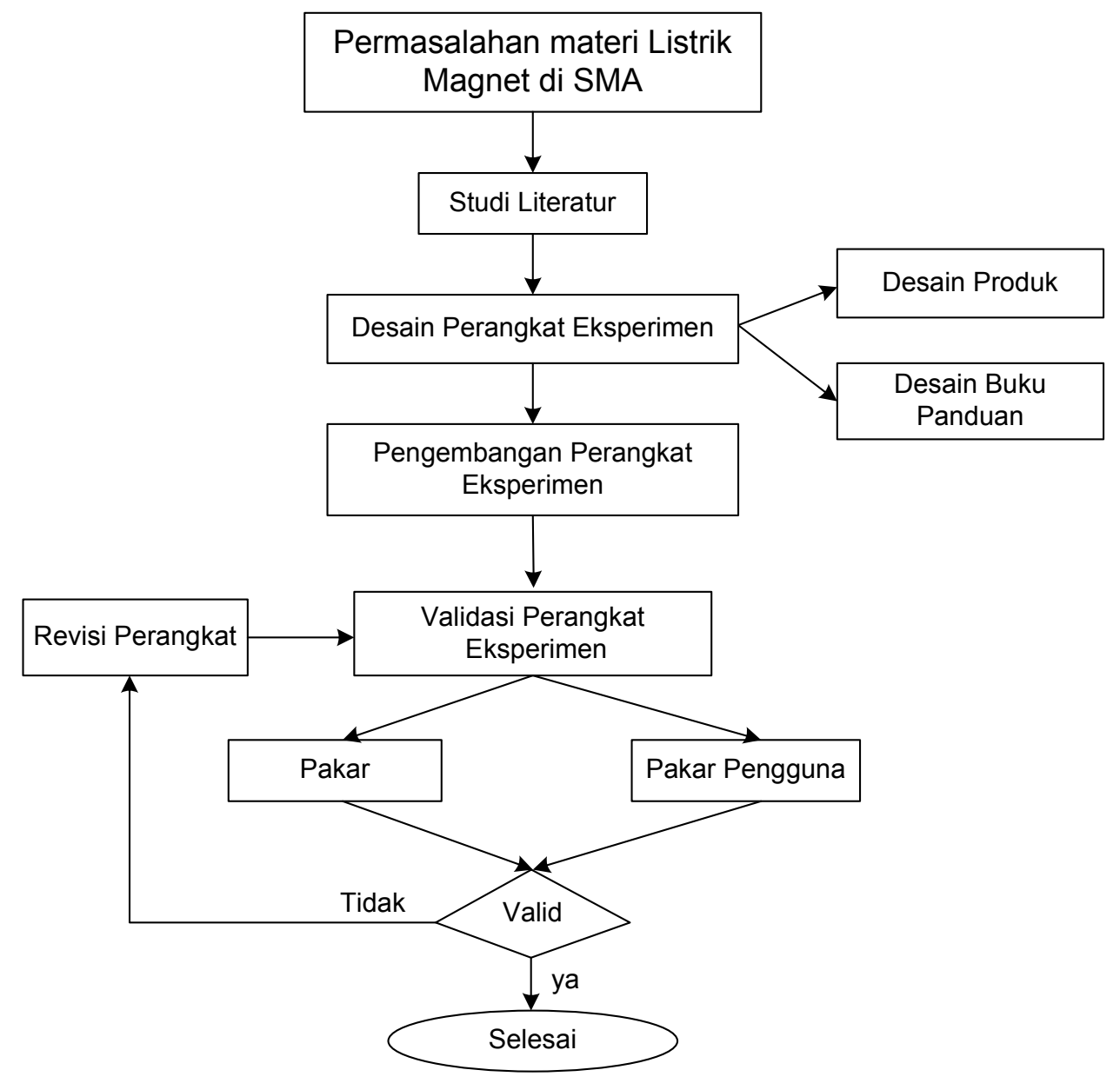

Gambar 1. Prosedur penelitian pengembangan perangkat eksperimen induksi magnetik pada kawat melingkar(Adaptasi N. J Manson dalam M.Rusdi, 2018). 
Tabel 1. Kriteria penilaian validitas alat eksperimen induksi magnetik (Johannesson, P. \& Perjons dalam M. Rusdi, 2018)

\begin{tabular}{|c|c|}
\hline Unsur-unsur & Penjelasan \\
\hline Kualitas Struktur & $\begin{array}{l}\text { Kualitas ini menjelaskan hal yang berkaitan dengan struktur } \\
\text { produk. }\end{array}$ \\
\hline Kualitas penggunaan & $\begin{array}{l}\text { Menjelaskan bagaimana produk seharusnya bekerja dan } \\
\text { dipandang dalam situasi penggunaannya. }\end{array}$ \\
\hline Management Qualities & Bagaimana produk mengelola waktu. \\
\hline Kualitas Lingkungan Generik & $\begin{array}{l}\text { Berhubungan dengan bagaimana produk secara struktural } \\
\text { berhubungan dengan lingkungannya. }\end{array}$ \\
\hline
\end{tabular}

Tabel 2. Unsur-unsur penilaian validitas panduan penggunaan alat eksperimen induksi magnetik pada kawat melingkar

\begin{tabular}{|c|c|}
\hline Unsur-unsur & Penjelasan \\
\hline Ketepatan isi & $\begin{array}{l}\text { Panduan yang berorientasi pada aktivtitas yang mendorong } \\
\text { keakuratan/ kesesuian prosedur kerja pada eksperimen } \\
\text { Induksi magnetik }\end{array}$ \\
\hline Penyajian & $\begin{array}{l}\text { Panduan penggunaan disusun sistematis dengan } \\
\text { memperhatikan keterpaduan antar konsep dan materi yang } \\
\text { disajikan. }\end{array}$ \\
\hline Bahasa & $\begin{array}{l}\text { Kesesuaian bahasa dengan perkembangan siswa, kaidah } \\
\text { bahasa Indonesia yang baik dan benar serta ketepatan } \\
\text { penggunaan simbol, istilah dan ikon. }\end{array}$ \\
\hline Kegrafikan/Tampilan & $\begin{array}{l}\text { Tata letak unsur grafika estetis, dinamis dan menarik serta } \\
\text { menggunakan ilustrasi yang jelas. }\end{array}$ \\
\hline
\end{tabular}

Sumber: (Panduan Penilaian Buku Teks Pelajaran Badan Standar Nasional Pendidikan).

Tabel 3 Kategori Penilaian Validitas Media

\begin{tabular}{cccc}
\hline No & Skor & Interval Skor & Kategori \\
\hline 1. & 4 & $3,25<$ rata-rata $\leq 4,00$ & Sangat Baik \\
2. & 3 & $2,5<$ rata-rata $\leq 3,25$ & Baik \\
3. & 2 & $1,75<$ rata-rata $\leq 2,5$ & Cukup Baik \\
4. & 1 & $1<$ rata-rata $\leq 1,75$ & Kurang baik \\
\hline
\end{tabular}

Sumber: (Muhammad Ulil Mubarok, 2018).

Perangkat eksperimen yang dibuat diharapkan dapat digunakan sebagai media pembelajaran fisika. Sebelum perangkat eksperimen digunakan sebagai media pembelajaran, perangkat eksperimen telah melewati beberapa validasi. Setelah melalui beberapa tahap validasi, maka perangkat eksperimen siap untuk digunakan sebagai media pembelajaran fisika.

\section{Hasil dan Pembahasan}

Perancangan perangkat eksperimen induksi magnetik pada kawat melingkar ini 
didasarkan pada rancangan percobaan yang dilakukan Hans Christian Oersted. Kemudian dimodifikasi sedemikian rupa dengan mempertimbangkan estetika, kemudahan dan keamanan saat digunakan. Peneliti berupaya merancang perangkat ekperimen dengan bentuk yang menarik, sederhana dan mudah digunakan. Perangkat eksperimen ini dirancang untuk beberapa percobaan diantaranya, menyelidiki pembentukan pola medan magnet menggunakan serbuk besi, mengidentifikasi medan magnet yang terjadi akibat kawat melingkar berarus dengan mengamati penyimpangan jarum kompas dan mengamati adanya gaya lorentz akibat kawat melingkar berarus pada kawat penghantar yang dialiri arus listrik. Pemilihan alat dan bahan yang digunakan juga menjadi pertimbangan utama. Bahan yang ringan, kuat dan mudah dibentuk seperti akrilik dipilih untuk menjadi kerangka dasar. Adapun alat eksperimen induksi pada kawat melingkar dapat dilihat pada Gambar 2.

Alat eksperimen terdiri atas beberapa bagian:

1. Catu daya 5 A untuk kumparan kawat melingkar

2. Catu daya $1 \mathrm{~A}$ untuk kawat penghantar

3. Kompas

4. Serbuk besi

5. Kawat penghantar

6. Lilitan kawat melingkar

7. Palu akrilik

8. Meja eksperimen terbuat dari akrilik

9. Kaki penyangga terbuat dari akrilik

10. Terminal

11.Kabel penghubung

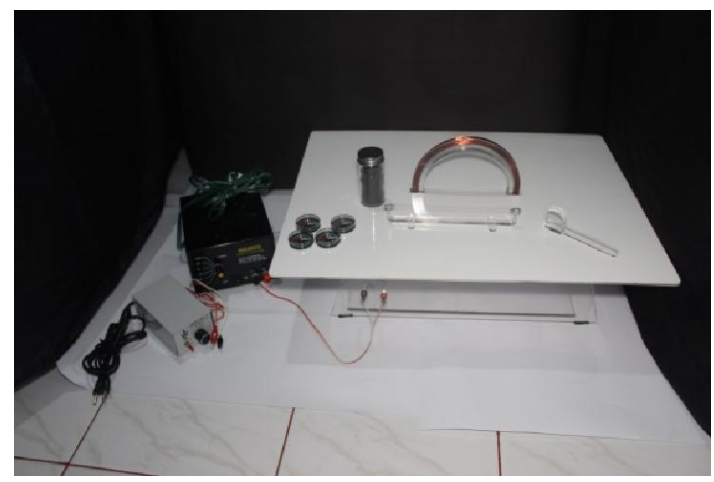

Gambar 2 Perangkat Eksperimen Induksi Magnetik pada Kawat Melingkar.
Dalam proses pembuatan alat eksperimen peneliti mengalami beberapa kegagalan, salah satunya dalam pembuatan meja perangkat. Semula meja perangkat terdiri dari dua lapis akrilik bening dan memiliki rongga untuk serbuk besi, agar saat lilitan kawat melingkar dialiri arus litrik pola-pola medan magnet dapat langsung terlihat. Pembuatan meja perangkat eksperimen seperti ini menyebabkan serbuk besi tidak dapat menyebar merata, hal ini menyebabkan pola medan magnet yang terbentuk tidak terlihat jelas. Sehingga harus dilakukan pembuatan ulang untuk meja perangkat dengan mehilangkan rongga untuk serbuk besi dan akrilik bening diganti dengan akrilik putih agar pola medan magnet dengan serbuk besi dapat terlihat lebih jelas.

Panduan penggunaan perangkat eksperimen induksi pada kawat melingkar berfungsi sebagai panduan penggunaan alat eksperimen serta penggunaan dalam melakukan percobaan yang telah dibuat. Panduan penggunaan perangkat eksperimen telah mengalami beberapa kali revisi baik itu perbaikan dari segi bahasa, desain maupun segi prosedur percobaan. Panduan penggunaan perangkat eksperimen terdiri dari cover, informasi komponen alat, lembar kerja peserta didik, serta petunjuk perawatan perangkat eksperimen yang dapat dilihat pada Gambar 3.

Peralatan eksperimen dan panduan penggunaan alat eksperimen dimuat dalam satu paket yang menjadi perangkat eksperimen induksi magnetik kawat melingkar. Setelah perangkat eksperimen dibuat, maka dilakukan validasi kepada tiga orang dosen dan dua orang guru fisika. Validasi yang dilakukan bertujuan untuk mengetahui apakah perangkat eksperimen sudah layak untuk digunakan atau belum.

Validasi pertama yang dilakukan pada alat eksperimen induksi magnetik pada kawat melingkar masih mengalami beberapa perbaikan. Perbaikan terhadap alat eksperimen induksi magnetik pada kawat melingkar dilakukan berdasarkan saran-saran yang diberikan validator. Setelah alat selesai diperbaiki maka dilakukan validasi kedua. Pada saat validasi kedua dilakukan validator memberikan nilai terhadap indikator dengan perolehan skor rata-rata validasi sudah mencapai kategori valid. Adapun hasil penilaian validasi dapat dilihat pada Tabel 4 . 


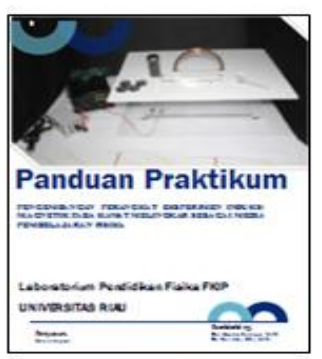

a)

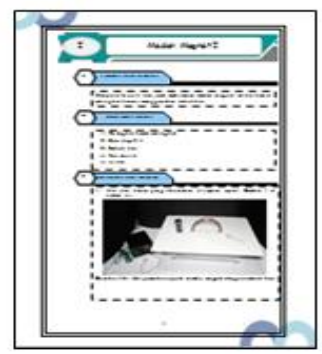

c)

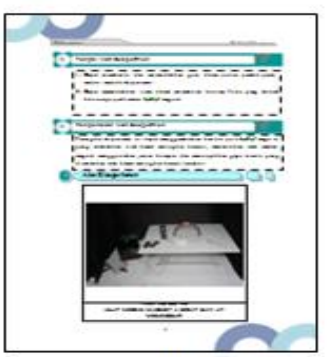

b)

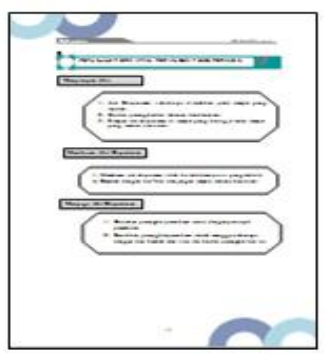

d)
Gambar 3. Perangkat eksperimen.

Keterangan: a) Cover panduan penggunaan perangkat eksperimen induksi magnetik pada kawat melingkar, b) informasi komponen alat c) LKPD percobaan induksi magnetik pada kawat melingkar, d) petunjuk perawatan perangkat eksperimen.

Berdasarkan hasil penilaian tiap-tiap aspek penilaian oleh validator yang terdapat pada Tabel 4 dapat dilihat hasil bahwa setiap aspek penilaian sudah berada pada rentang rata-rata skor 3,15 sampai 3,46 dengan tingkat validitas baik sampai sangat valid. Dengan demikian, secara keseluruhan alat eksperimen induksi magnetik pada kawat melingkar sudah dapat dikatakan valid dengan skor rata-rata seluruhnya yaitu 3,34 dengan kategori sangat baik.

Validasi panduan penggunaan alat eksperimen dilakukan dengan cara yang sama seperti validasi alat eksperimen. Validasi tahap pertama yang dilakukan oleh validator banyak memberikan saran-saran untuk perbaikan panduan penggunaan alat esperimen. Setelah selesai diperbaiki berdasarkan saran-saran validator, maka panduan penggunaan alat eksperimen siap untuk validasi tahap kedua oleh validator. Setelah validasi kedua selesai dilakukan maka didapatkan hasil skor ratarata sudah valid. Adapun hasil penilaian dari validator dapat dilihat pada Tabel 5.
Tabel 4 Penilaian Validitas Alat Eksperimen Induksi Magnetik pada Kawat Melingkar

\begin{tabular}{clcc}
\hline No & Aspek Penilaian & Nilai & $\begin{array}{c}\text { Kategori } \\
\text { Validitas }\end{array}$ \\
\hline 1 & Kualitas Struktur & 3,15 & $\mathrm{~B}$ \\
2 & $\begin{array}{l}\text { Kualitas } \\
\text { Penggunaan }\end{array}$ & 3,36 & $\mathrm{SB}$ \\
3 & $\begin{array}{l}\text { Management } \\
\text { Qualities } \\
\text { Kualitas } \\
4\end{array}$ & 3,40 & $\mathrm{SB}$ \\
& $\begin{array}{l}\text { Lingkungan } \\
\text { Generik }\end{array}$ & 3,46 & $\mathrm{SB}$ \\
\hline $\begin{array}{l}\text { Rata-rata Nilai } \\
\text { Validitas }\end{array}$ & 3,34 & $\mathrm{SB}$ \\
\hline
\end{tabular}

Tabel 5. Hasil Penilaian Validasi Panduan Penggunaan Alat Eksperimen Induksi Magnetik pada Kawat Melingkar

\begin{tabular}{clcc}
\hline No & $\begin{array}{c}\text { Aspek } \\
\text { penilaian }\end{array}$ & Nilai & $\begin{array}{c}\text { Kategori } \\
\text { Validitas }\end{array}$ \\
\hline 1. & $\begin{array}{l}\text { Ketepatan isi } \\
\text { Kelayakan } \\
\text { 2. }\end{array}$ & 3,5 & $\mathrm{SB}$ \\
$\begin{array}{l}\text { Penyajian } \\
\text { Kelayakan }\end{array}$ & 3,3 & $\mathrm{SB}$ \\
B. & 3,4 & $\mathrm{SB}$ \\
$\begin{array}{l}\text { Kasasa } \\
\text { Kelayakan } \\
\text { Tampilan }\end{array}$ & 3,67 & $\mathrm{SB}$ \\
\hline Rata-rata Nilai & 3,47 & $\mathrm{SB}$ \\
\hline
\end{tabular}

Berdasarkan Tabel 5 didapatkan hasil bahwa setiap aspek penilaian validasi panduan penggunaan alat eksperimen sudah dapat dikatakan valid dengan skor rata-rata semua aspek sebesar 3,47 dengan kategori sangat baik

Secara keseluruhan alat dan panduan penggunaan alat eksperimen induksi magnetik pada kawat melingkar sudah dapat dikatakan valid dengan kategori sangat baik sehingga panduan penggunaan alat eksperimen sudah layak digunakan dan layak untuk dilakukan uji praktikalitas. Terlepas dari semuanya, alat percobaan yang dibuat perlu adanya penyempurnaan dan perbaikan. Adapun kelebihan dari alat percobaan ini adalah jika dibandingkan dengan alat percobaan induksi magnetik pada kawat melingkar yang digunakan sebelumnya yaitu terdapat beberapa variasi percobaan yang dapat dilakukan yaitu 
dapat memperliahtkan pola medan magnet akibat induksi pada kawat melingkar dengan serbuk besi, melihat besarnya medan magnet akibat induksi kawat melingkar dengan melihat arah dan besar penyimpangan jarum kompas, dan mengamati adanya gaya lorentz yang terjadi pada kawat penghantar berarus akibat induksi magnetik pada kawat melingkar.

Adapun kekurangan dari perangkat percobaan induksi magnetik pada kawat melingkar ini adalah tidak dapat melihat pengaruh diameter kawat dan banyaknya kumparan yang digunakan terhadap medan magnet yang terbentuk karena hanya menggunakan satu jenis kawat dan satu jenis lilitan. Masih memerlukan perbaikan pada struktur alat eksperimen dalam penggunaan serbuk besi agar leih ramah lingkungan dan waktu penggunaan alat yang membutuhkan waktu jeda agar alat eksperimen tidak panas dan terbakar serta penggunaan bahan akrilik yang mudah pecah.

\section{Kesimpulan dan Saran}

Sebuah perangkat eksperimen induksi magnetik pada kawat melingkar telah berhasil dikembangkan dengan mengikuti langkahlanglah atau tahap ilmiah prosedur penelitian, yaitu: permasalahan dalam materi medan magnet di SMA, studi literatur, desain perangkat eksperimen, pembuatan perangkat eksperimen dan validasi perangkat eksperimen. Proses validasi oleh validator memperhatikan aspek kualitas struktur, kualitas penggunaan, management qualities dan kualitas lingkungan generik pada alat eksperimen. Hasil perolehan skor validasi alat eksperimen induksi magnetik pada kawat melingkar secara keseluruhan memiliki kategori tingkat validitas sangat baik. Sedangkan validasi panduan penggunaan alat eksperimen induksi magnetik pada kawat melingkar memperhatikan aspek ketepatan isi, kelayakan penyajian, kelayakan bahasa dan kelayakan tampilan dengan perolehan skor rata-rata secara keseluruhan memiliki tingkat kategori validitas sangat baik.

Berdasarkan perolehan skor validasi secara keseluruhan maka alat eksperimen induksi magnetik pada kawat melingkar dan buku panduan penggunaan alat eksperimen dinyatakan valid dan layak digunakan sebagai media pembelajaran fisika SMA.

Pada penelitian yang telah dilakukan oleh penulis ini hanya terbatas pada perancangan, pembuatan perangkat eksperimen induksi magnetik pada kawat melingkar, serta pengujian validitas dari perangkat eksperimen yang telah dibuat. Sebagai rekomendasi dari penulis, perangkat eksperimen induksi magnetik pada kawat melingkar yang sudah dibuat ini dapat dilanjutkan dengan uji praktikalisasi ke sekolah-sekolah sebagai media pembelajaran fisika SMA.

\section{Daftar Pustaka}

Afdan, 2012. Medan Magnet disekitar Kawat Berarus Listrik. https://pustakafisika. wordpress.com/2012/09/18/medanmagnet-disekitar-kawat-beraruslistrik/.(Diakses tanggal 20 Maret 2018).

Cepy Riyana. 2012. Media Pembelajaran. Direktorat Jendaral Pendidikan Islam Kementrian Agama RI. Jakarta.

Douglas Giancoli, 2001. Fisika. Jilid 2. Erlangga. Jakarta.

Hamzah, M. Ali \& Muhlisrarini. 2014. Perencanaan dan Strategi Pembelajaran Matenatika. Rajagrafindo Persada. Jakarta.

Ika Risqi. 2014. Pengaruh Media Audio-Visual (Vidio) Terhadap Hasil Belajar Siswa Kelas XI pada Konsep Elastisitas. Prosiding Seminar Nasional Pendidikan IPA FITK UIN Syarif Hidayatullah. 11 September 2014. UIN Syarif Hidayatullah. Jakarta.

Irnin Agustina Dwi Astutia. 2017. Pengembangan Media Pembelajaran Fisika Mobile Learning berbasis Android. JPPPF. 3(1). 57-62. (online). http://doi.org/10.21009/1. (diakses 28 januari 2019).

M. Rusdi. 2018. Penelitian Desain dan Pengembangan Kependidikan. Rajawali Pers. Jakarta.

Muhammad Ivan, 2015. Pengembangan Alat Pratikum Medan Magnet Sebagai Media Pembelajaran fisika. E-jurnal SNF 2015. Oktober 2015. FKIP UNJ. Jakarta 
Muhammad Ridho. 2017. Pengembangan Perangkat Eksperiment Oersted sebagai Media Pembelajaran Fisika SAM. Jurnal Online Mahasiswa bidang Keguruan dan Ilmu Pendidikan Vol. 4 No. 2. (Online). http://ejournal.unri.ac.id. (Diakses Maret 2018).

Muhammad Suin. 2012. Hukum Biot Savart. http://muhsuinelektronikablogspot.co.id /2012/05/hukum-nio-savart.html. (Diakses tanggal 20 Maret 2018)

Muhammad Ulil Mubarok. 2018. Pengembangan Media Pembelajaran Matematika dengan Power Point VBA pada Materi Sistem Persamaan Linear Tiga Variabel. Prosiding Seminar Nasional Integrasi Matematika dan Nilai Islami. 1 Desember 2018. IAIN Tulungagung. Jawa Timur.
Munadi, Yudhi. 2010. Media Pembelajaran: Sebuah Pendekatan Baru. Gaung Persada (GP) Press. Jakarta.

Oktafiani, Silvia Nur, Zulirfan, \& Sudrajad, Hendra. 2015. Studi Pendahuluan Pengembangan Perangkat Eksperimen Induksi Elektromagnetik Alternatif Sebagai Media Pembelajaran Fisika SMA. Jurnal Online Mahasiswa bidang Keguruan dan Ilmu Pendidikan Vol 3. Nomor 1. (Online). http://ejournal.unri. ac.id. ( diakeses Mai 2019).

Siti Maghfirotun dan Heri Kiswanto, 2011. Pengembangan Media Pembelajaran Interaktif Berbantuan Komputer pada Materi Dimensi Tiga. E-Journal UNESA. 1 (1). p.3-4. (Online). www.jurnalmahasiswa.unesa.ac.id. (diakses 29 November 2018).

Tipler, Paul, A., 2001. FISIKA Untuk Sains dan Teknik. Jilid Erlangga, Jakarta. 